\author{
JOLANTA SUJECKA \\ Uniwersytet Warszawski \\ Warszawa, Polska
}

\title{
Dlaczego literatura macedońska nie chce być literaturą mniejszą?
}

Określenie „literatury mniejsze” od czasu publikacji w 1975 roku słynnej monografii poświęconej pisarstwu Franza Kafki ${ }^{1}$, autorstwa francuskiego duetu: filozofa Gilles'a Deleuze'a i psychiatry Félixa Guattari'ego, stało się integralną częścią współczesnego dyskursu filozoficznego, teoretycznoliterackiego oraz historycznoliterackiego.

I choć Deleuze i Guattari budują swoją typologię w oparciu o pisarstwo wybitnych twórców - Franza Kafki, Samuela Becketta, Jamesa Joyce'a, to przez wielu badaczy późniejszych (aż do dziś) jest ona stosowana w odniesieniu do twórczości, która niejako „wyszła” z większej kulturowej całości, jak choćby literatura romańskiej Szwajcarii czy Belgii ${ }^{2}$. Jednym wszak z ważniejszych aspektów wspomnianej typologii wydaje się próba uchwycenia na gorąco nieuchronnych procesów związanych z narodzinami tak zwanych nowych tożsamości i w tym kontekście termin Deleuze'a i Guattari'ego staje się swoistym kluczem, ułatwiającym zrozumienie skomplikowanych relacji między centrum a regionem oddzielającym się od wspólnoty językowo-kulturowej, której był częścią.

W niniejszym artykule chciałabym zastanowić się nad sytuacją literatury macedońskiej nie po II wojnie światowej, kiedy literatura ta zyskuje pełne instytucjonalne oparcie, lecz w okresie, gdy rodził się jej projekt w ramach Macedońskiego Koła Literackiego w Sofii, czyli w latach 1938-194133.

${ }^{1}$ Angielskie thumaczenie ukazało się w 1986 roku.

2 Mam tu na uwadze wydany cztery lata temu tom poświęcony literaturom romańskiego kręgu kulturowego: Literatury mniejsze Europy romańskiej, red. M. Loba, B. Łuczak, A. Gregori, Poznań 2012.

${ }^{3}$ Wielu badaczy, m.in. Blaže Ristovski (idem, Националната свест во литературно-културната дејност на Македонскиот литературен кружок во Софија, „Прилози. Одделе- 
Tworzony przez Michaiła Smatrakaleva i Nikolę Vapcarova ${ }^{4}$ (oraz pozostałych członków Koła) projekt literatury macedońskiej spełnia (podawany przez Deleuze'a i Guattariego jako warunek sine qua non) postulat deterytorializacji, czyli koniecznego dystansu od strefy stanowiącej właściwe terytorium macedońskiej wspólnoty językowo-kulturowej. Z punktu widzenia ówczesnej oficjalnej Bułgarii zarówno Macedonia, jak i Słowianie macedońscy traktowani są jako Bułgarzy, o czym pisałam w artykule Bałkańskie miejsca pamięci, opublikowanym także w Bułgarii ${ }^{5}$. Macedońskie Koło Literackie w Sofii ${ }^{6}$ było środowiskiem komunizującej lewicy; rozgrywające się na jego łonie niezwykle interesujące, bo wieloaspektowe, kwestie tożsamościowe należy zatem rozpatrywać w kontekście ewoluującego stanowiska komunistycznych partii na Bałkanach w odniesieniu do kwestii macedońskiej ${ }^{7}$. Niewątpliwie ciekawe tło oficjalnej Bułgarii przełomu lat trzydziestych i czterdziestych było tematem większości opracowań zarówno bułgarskich, jak i macedońskich. Stanowisko dominującego nurtu dyskursu edukacyjnego w dzisiejszej Republice Macedonii w odniesieniu do Macedońskiego Koła Literackiego w Sofii, choć samo w so-

ние за лингвистика и литературна наука” XXII, 1997, nr 1-2, s. 169-170) próbuje cofać dzieje Macedońskiego Koła Literackiego w Sofii do roku 1936, czyli - jak podaje jeden z członków (założycieli) Koła - Michaił Smatrakalev (1910-1998) w swoim liczącym 26 pudeł archiwum do efemerycznej organizacji Публицистичен Кръжок [Koło Publicystyczne], która powstała w 1936 roku po zamknięciu bardzo ważnego dla macedońskiej diaspory w Sofii tygodnika Angeła Dineva (1891-1952) „Македонски вести” (1935-1936). Takie działanie ma na celu „uzupełnianie luk” w budowanym po II wojnie światowej kanonie narodowej tożsamości Macedończyków i jest próbą poprawiania historii. Jednocześnie zaciera naturalny proces stawania się narodu, który w odniesieniu do Macedończyków był wyjątkowo skomplikowany. Zob. Фонд М. Сматракалев, кутија 10, Архив на Република Македонија (dalej: Сматракалев, кутија 10); Macedonia: Land, Region, Borderland, conception and academic editing J. Sujecka, Warszawa 2013, s. 137-227.

${ }^{4} \mathrm{Na}$ użytek tego artykułu przyjmuję następujący zapis imienia i nazwiska poety: Nikola Vapcarov, choć w polskiej tradycji funkcjonuje zapis Nikoła Wapcarow, co wynika raczej z bezdyskusyjnego w narracji polskich badaczy przyporządkowania poety i jego twórczości do kanonu literatury bułgarskiej. Nazwiska bułgarskie zaś, podobnie jak rosyjskie, w polskiej tradycji transliterujemy zgodnie z zasadami zaproponowanymi przez Mieczysława Szymczaka w Słowniku języka polskiego. Kwestii złożonej tożsamości poety poświęciłam jeden z podrozdziałów monografii grantowej Macedonia: Land, Region, Borderland, która ukazała się pod moją redakcją w 2013 roku, zatytułowany The Macedonian literary circle in Sofia 1938-1941 (s. 187-198).

5 J. Sujecka, Batkańskie miejsca pamięci. Pojęcie Macedonii w bułgarskiej i macedońskiej czasoprzestrzeni kulturowej XX w., „Borussia” 2006, nr 37, s. 76-88; еаdeт, Балкански места на паметта. Терминът Македония и образът наНикола Вапиаров в блгарския и македонския времепространствен континуум, „Литературна мисьл” 2005, nr 2, s. 138-154.

${ }^{6}$ Nazwa koła ma zarówno bułgarską wersję - „Македонски литературен кръжок”, jak i wersję macedońską — „Македонски литературен кружок во Софија”.

7 J. Sujecka, Pojęcie Macedonii w wybranych dokumentach, publicystyce i tekstach folkloru z pierwszej połowy XX wieku. Od idei stowiańskiej jedności do federacji batkańskiej, [w:] Między kultura ,"niska” a ,wysokq": zjawiska językowe, literackie, kulturowe. Pamięci prof. dr hab. Teresy Dąbek-Wirgowej, red. M. Korytkowska, Z. Darasz, G. Minczew, Łódź 2001, s. 133-140. 
bie zajmujące, nie jest bezpośrednim, znaczącym kontekstem dla rozważanych w tym artykule kwestii ${ }^{8}$.

Macedońska tożsamość, jaką możemy obserwować przez cały okres istnienia Koła, zwykle traktowana jest przez jego badaczy jako gotowy produkt, nie zaś jako proces stawania się, stanowiący idealną ilustrację zaproponowanej przez Deleuze'a i Guattariego typologii literatur mniejszych. Oprócz warunku deterytorializacji (rozumianej przez francuskich badaczy bardzo szeroko), jako cechy literatur mniejszych wymieniają oni także ich upolitycznienie oraz przypisanie do nich tak zwanych wartości kolektywnych, wspólnotowych. Z tego właśnie powodu projekt literatury macedońskiej kształtujący się w obrębie Macedońskiego Koła Literackiego w Sofii wydaje się szczególnie ciekawy.

Wszyscy zrzeszeni w nim pisarze i poeci działali w Sofii, miejscu wyjątkowo intensywnej aktywności diaspory macedońskiej, a zatem w pewnej odległości zarówno od Macedonii Wardarskiej, czyli terytorium dzisiejszej Republiki Macedonii, jak i poza Macedonią Piryńską, należącą w tamtym okresie (podobnie jak dziś) do Bułgarii. W dodatku tylko dwóch członków Koła - Kole Nedelkovski i Venko Markovski - jak zaświadcza Michaił Smatarkalev (Сматракалев, кутија 10), pisało w języku lokalnym, czyli w języku używanym na terenie Macedonii Wardarskiej, określanej wówczas południową Serbią i wchodzącej w obręb Królestwa Jugosławii.

Deleuze i Guattari w rozdziale poświęconym literaturom mniejszym podkreślają, że koncepcja nie jest prostą pochodną „mniejszego języka”, a „konstrukcją mniejszości wewnątrz języka większości”. To, co jednak najlepiej określa literatury mniejsze (w każdym miejscu pod słońcem), zdaniem francuskich badaczy dotyczy ich języka, ,zainfekowanego współczynnikiem deterytorializmu”:

A minor literature doesn't come from a minor language; it is rather that which a minority constructs within a major language. But the first characteristic of minor literature in any case is that in it language is affected with a high coefficient of deterritorialization. In this sense, Kafka marks the impasse that bars access to writing for the Jews of Prague and turns their literature into something impossible - the impossibility of not writing, the impossibility of writing in German, the impossibility of writing otherwise. The impossibility of not writing because national consciousness [wyr. J.S.], uncertain or oppressed, necessarily exists by means of literature ("The literary struggle has its real justification at the highest possible levels"). The impossibility of writing other than in German is for the Prague Jews the feeling of an irreducible distance from their primitive Czech territoriality. And the impossibility of writing in German is the deterritoralization of the German population itself, an oppressive minority that speaks a language cut off from the masses, like a "paper language" or an artificial language; this is all the more true for the Jews who are simultaneously a part of this minority and excluded from it, like "gypsies who have stolen a German child from its crib." In short, Prague German is a deterritorialised language, appropriate for strange and minor uses 9 .

${ }^{8}$ В. Тоциновски (избор, превод, редакција и белешки), Македонскиот Литературен Кружок, Софија, 1938-41, Документи, Скопје 1995.

${ }^{9}$ G. Deleuze, F. Guattari, Kafka: Toward a Minor Literature, przeł. D. Polan, „Theory and History of Literature" 30, Minneapolis-London 1986, s. 16-17. 
Deterytorializm prowadzi do paraliżu sił twórczych, uniemożliwiając pisarstwo w języku opresyjnym, który zaczyna być językiem niekompatybilnym z własną, nową - kształtującą się — tożsamością, narodową, społeczną, kulturową (genderową ${ }^{10}$ ).

Analizowany przez Smatrakaleva na drugim spotkaniu Koła wiersz Vapcarova Родина ${ }^{11}$, opublikowany w języku bułgarskim trzy lata wcześniej na łamach bułgarskiego tygodnika „Кормило”, organu Bułgarskiej Partii Komunistycznej, choć jednocześnie czasopisma otwartego dla niepartyjnych twórców (jakim był w chwili publikacji liryku Vapcarov), został odczytany w tym właśnie kluczu rodzącej się świadomości deterytorializacji języka:

Стихотворението е македонско. В него виждаме издигнатите гранити на Пирин, орлите над бедните села, но не само тая картина го прави македонско, не. Навсякаъде образа на родината е някак неразривно свързан с автора. И когато го боли и когато страда, той се отчайва и хули майка си, хули я не че му е далечна, а защото му е близка, защото на майката, найблизката, той може да каже най-горчивите и най-нежни думи. И като отрезнява, той ги казва неподражаемо просто - “Сега си ми близка, по-близка от майка дори!” И на края неговия устрем естествено е свързан с имената на Гоце и Даме. Но има и друго. Тука има и навлизане и към интернационализма $[\ldots]^{12}$ (Сматракалев, кутија 10).

Naturalnym kontekstem, przesuwającym akcenty lektury, są wypowiedzi poety na temat projektu literatury macedońskiej. Jak podaje w 1945 roku w swoich wspomnieniach Michaił Smatrakalev, Vapcarov w wygłoszonym na pierwszym spotkaniu (i - jak zaświadcza Samtrakalev — niezapisanym ${ }^{13}$ ) referacie moc-

${ }^{10}$ Ważny dział literatur mniejszych stanowi literatura queer.

11 „Кормило” 1, 17 czerwca 1936, nr 37, s. 3.

12 „Wiersz jest macedoński. Widzimy w nim wyniesione granity Pirynu, orły nad biednymi wsiami, ale nie tylko ten obraz czyni z niego macedoński [utwór - J.S.], nie. Wszędzie jakoś obraz ojczyzny jest związany z autorem. I kiedy go boli, i kiedy cierpi, i kiedy jest zdesperowany i przeklina swoją matkę, przeklina ją nie dlatego, że jest od niego oddalona, ale dlatego, że jest mu bliska, dlatego, że matce, najbliższej, może powiedzieć najsmutniejsze [najbardziej gorzkie] i najdelikatniejsze słowa. I kiedy przytomnieje, mówi zwyczajnie w sposób nie do podrobienia: »Teraz jesteś mi bliska — bliższa nawet od matki!« I na koniec jego dążenie jest związane w sposób naturalny z Goce [Delčevem — J.S.] i Dame [Gruevem — J.S.]. Ale jest i coś innego. Tutaj jest także odniesienie do internacjonalizmu [...]" (thum. J. Sujecka).

${ }^{13}$ W cytowanej już monografii Macedonia: Land, Region, Borderland podaję za archiwum Smatrakaleva dokładny spis członków Macedońskiego Koła Literackiego, cytuję również wypowiedź Smatarkaleva na temat osławionego pierwszego referatu Vapcarova, wygłoszonego na pierwszym spotkaniu i zgodnie z twierdzeniem uczestnika wydarzeń, jakim był Smatrakalev, nigdy niezapisanego. Pomysł zapisywania referatów zrodził się właśnie po pierwszym spotkaniu, dlatego Michail Smatrakalev rekonstruuje jego treść z pamięci (Macedonia: Land, Region, Borderland..., s. 187-198). Na temat pierwszego referatu Vapcarova istnieje obszerna literatura przedmiotu, w macedońskiej narracji przyjmuje się w istocie bezdyskusyjnie istnienie referatu (zob. Б. Ристовски, Беседа за делото на Вапиаров, [w:] Свечен собир по повод 80-годишнината од раѓането на Никола Вапцаров (17.X.1989), red. К. Томовски, Скопје 1990, s. 5-23; В. Тоциновски, op. cit., s. 41-44). W opublikowanym w 1997 roku artykule Blaže Ristovski (Б. Ристовски, Националната свест..., s. 169-170) podaje nieco zmienioną wersję na ten temat. Wydaje się, że kwestia ta wyma- 
no podkreślał konieczność włączenia do projektu literatury macedońskiej tematu związanego z Macedonią, z wysoką jakością artystyczną utworów. Wkrótce myśl poety rozwinął także Smatrakalev, który twierdził wręcz, że macedońska poezja, jako całkiem nowe zjawisko, powinna być nowatorska, oryginalna w sposobie ekspresji — nowe obrazy wymagają bowiem nowatorskiej, oryginalnej formy.

Społeczny wymiar poezji Vapcarova, tak charakterystyczny dla jego wierszy, zarówno tych znanych z bułgarskiej prasy, jak i tych opublikowanych w jedynym tomiku poetyckim z 1940 roku - Моторни песни ${ }^{14}$, odczytywany w kontekście wypowiedzi Smatrakalewa (i samego poety) nabiera cech uniwersalizmu, charakteryzującego każdą wielką, ponadnarodową literaturę.

Wydaje się ponadto, że problem z Vapcarovem jest w istocie sporem o wartość uniwersalną jego utworów. W cytowanym już artykule poświęconym między innymi bułgarskiemu i macedońskiemu obrazowi poety ${ }^{15}$ pisałam, że społeczny aspekt jego utworów był eksponowany w czasach komunistycznej Bułgarii, natomiast Vapcarov-patriota jest obrazem zakorzenionym w edukacyjnym dyskursie macedońskim. Obydwa wymiary jego poezji doskonale mieszczą się w projekcie literatur mniejszych, zarazem jednak każdy z nich osobno sytuuje ją poza obrębem zarówno tak zwanej poezji proletariackiej, do której próbowano go włączyć, jak i poza projektem literatury narodowej.

Osobnego potraktowania wymaga również - wcale nie tak oczywista, jak by się wydawało - kwestia centrum, od którego odcina się poezja Vapcarova. Dla Vapcarova-poety o zdecydowanie lewicowych poglądach, nawet jeszcze przed formalnym wstąpieniem do Bułgarskiej Partii Komunistycznej, centrum lokuje się w przestrzeni sprawiedliwości społecznej, rozumianej trochę utopijnie, lecz także stosunkowo wcześnie łączonej ze środowiskiem tak zwanej poezji proletariackiej, mimo że w jej ,jakościowej” odmianie. Mam tu na uwadze twórców komunistycznej i niekomunistycznej lewicy skupionych wokół organu partii komunistycznej „Кормило” (1935-1936), czyli ‘ster', którzy z powodu przywiązywania jednakowej wagi do zawartości ideowej utworów oraz ich formy artystycznej zostali oskarżeni o popieranie idei czystej sztuki, co doprowadziło do odejścia ,jakościowców" z partii.

„Кормило” ukazywało się w Sofii dokładnie w tym samym czasie co „Македонски вести” Angeła Dineva, aczkolwiek Vapcarov ze środowiskiem macedońskiej diaspory zetknął się (podobnie jak inny członek Koła - Anton Popov) dopiero po rozwiązaniu obydwu czasopism. Należy przypomnieć, że z bułgarskim, proletariackim tygodnikiem współpracował także Michail Smatrakalev, główny

ga wnikliwego zbadania, albowiem znajdujące się w Archiwum Republiki Macedonii najpełniejsze, liczące 26 pudeł, choć nieuporządkowane archiwum Smatrakaleva nie potwierdza tego faktu.

${ }^{14}$ Większość utworów z tomiku Моторни песни została przetłumaczona na język polski i opublikowana w zbiorze Pieśni wybrane Wapcarowa w opracowaniu i thumaczeniu Jerzego Laua, wydanym w 1954 roku przez Wydawnictwo Książka i Wiedza.

15 Й. Суецка, Балкански места на паметта..., s. 138-154. 
animator Koła. To właśnie przyjaźń Vapcarova ze Smatrakalevem zadecydowała o powołaniu do życia Macedońskiego Koła Literackiego, a także o korekcie punktu odniesienia jego twórczości, czyli o kreacji nowego centrum. Projektowana w jego poezji przestrzeń sprawiedliwości społecznej nie znika wraz z likwidacją organu Bułgarskiej Partii Komunistycznej (BKP), lecz zaczyna się łączyć z macedońską kwestią. Połączenie to jest bardzo dobrze widoczne w zaprezentowanej przez Smatrakaleva na drugim zebraniu Koła analizie pięknego liryku Vapcarova Родина przypomnijmy, opublikowanego dwa lata wcześniej na łamach oficjalnego organu ВРК „Кормило”.

Poezja Vapcarova dla tego pierwszego centrum, czyli szeroko rozumianego (z wyłączeniem ,jakościowców”) środowiska literatury proletariackiej, jest trudna do zaakceptowania, nie mieści się w kanonie, wiele zawdzięcza tradycji bułgarskiej poezji modernistycznej, a zwłaszcza bliskiej symbolizmowi poezji Pejo Jaworowa $^{16}$, przede wszystkim jednak jest wyraźnie zakorzeniona w awangardowej poezji rosyjskiej — chodzi tu nie tyle o Włodzimierza Majakowskiego (na którego zwykle wskazują badacze), lecz raczej o poezję Anny Achmatowej i jej bułgarskiej kontynuatorki z lat trzydziestych - Elisawety Bagrainy ${ }^{17}$. Drugie centrum to Macedonia w lirykach z Моторни песни, przywoływana poprzez pejzaż, postaci historyczne Goce Delčeva i Dame Grueva (notabene w ogóle nieistniejące w ówczesnej bułgarskiej świadomości ${ }^{18}$ ). Na styku pierwszego i drugiego centrum następuje modyfikacja znaczeń i w tym układzie odniesień sytuuje się projekt literatury macedońskiej animowany przez Vapcarova i Smatrakaleva.

Kluczowy dla pełnego zrozumienia zarówno postaci Vapcarova, jak i jego poezji, a wreszcie nielicznych wypowiedzi programowych, jest drażliwy dla wielu badaczy, nie tylko bułgarskich czy macedońskich, lecz także zagranicznych problem tożsamości autora Моторни песни i jego najbliższego otoczenia z Macedońskiego Koła literackiego w Sofii. Kwestia ta jest zwykle przez badaczy traktowana zbyt jednoznacznie albo nie jest poruszana w ogóle ${ }^{19}$. Tymczasem - jak

16 Warto odnotować, że poezja Pejo Jaworowa cieszyła się ogromną popularnością także wśród członków macedońskiego Koła Literackiego w Sofii (Сматракалев, кутија 10).

17 Na poezję Włodzimierza Majakowskiego powołuje się Michaił Smatrakalev w swojej analizie wiersza Vapcarova Родина. Ta paralela służy przede wszystkim wyjaśnieniu słuchaczom-członkom Koła wagi nie tylko przesłania ideowego wiersza, ale też jego artystycznego zaplecza (Сматракалев, кутија 10; Macedonia: Land, Region, Borderland..., s. 187-198).

18 Szczególną rolę w propagowaniu postaci Goce Delčeva i Dame Grueva, a także w kreacji kanonu bojowników o autonomię Macedonii z czasów powstania Ilindenskiego z 1903 roku odegrały czasopisma redagowane przez Arseni Jovkova (1882-1924) w Sofii, w pierwszej połowie lat dwudziestych XX wieku: „Илинденъ”, „Пиринъ”, „20 Юули” (Фонд Арсени Јовков 1882-1924, Архив на МАНУ). Umieszczano w nich biogramy i portrety słynnych przywódców powstania, lecz także znanych komitów, co z jednej strony było próbą upamiętnienia ich, z drugiej zaś układało się w swoisty kanon bohaterów jednoczących diasporę macedońską w Sofii.

19 W Historii Macedonii Irena Stawowy-Kawka kwalifikuje Vapcarova jednoznacznie jako bułgarskiego poetę, a Macedońskie Koło Literackie w Sofii jako grupę lokalnych, regionalnych twórców (eadem, Historia Macedonii, Wrocław 2000, s. 203). Z kolei Terasa Dąbek-Wirgowa unika 
zaświadcza Smatrakalev — dla autora Родина Macedonia i macedońskość stanowiły pewnego rodzaju odkrycie. Szczególnie ciekawe pod tym względem wydają się bardzo emocjonalne reakcje poety na wiadomość o wizycie młodzieży z Macedonii Wardarskiej w Sofii (Сматракалев, кутија 10). Z tego punktu widzenia spisana przez Smatrakaleva (prezentowana na pierwszym spotkaniu Koła własna lektura liryku Родина) jest znakomitym dokumentem ewoluującej tożsamości autora wiersza.

W tym kontekście zarówno wszelkie próby wpisywania Vapcarova i jego twórczości w jeden narodowy kanon, bułgarski czy macedoński, jak i zamykanie go w jednoznacznych, stygmatyzujących określeniach: „poeta proletariacki”, „poeta patriotyczny”, ,poeta komunista” wydają się uproszczeniem skomplikowanego procesu kształtowania własnej osobowości twórczej i tożsamości.

Alternatywne określenia dla niejednoznacznych identyfikacji, jakie proponuje część macedońskiej krytyki, zarówno z diaspory, jak i z kraju, między innymi Ivan Dorovský ${ }^{20}$ czy Milan Ǵurčinov ${ }^{21}$, nie oddają skomplikowanej natury procesu. Obydwaj krytycy używają bowiem określenia „dvodomen/trodomen poet/ pisatel", co oznacza poetę/pisarza, który posiada dwie lub trzy ojczyzny/domy, czyli rodzaj podwójnego/potrójnego obywatelstwa ${ }^{22}$. Tymczasem w odniesieniu do Vapcarova należałoby raczej mówić o tożsamości wielowarstwowej, co zakłada pewną naturalność zjawisk konwergencji kulturowo-tożsamościowej jako

jakiejkolwiek kwalifikacji narodowej w odniesieniu do autora liryku Родина, całą uwagę skupiając na ukazaniu przełomowego charakteru jego poezji, pomija także kwestię działalności poety w Macedońskim Kole Literackim (eadem, Historia literatury butgarskiej, Wrocław 1980, s. 195-212, 236-239). Ta ostrożność badaczki wynikała, jak sądzę, z głębokiego przekonania o istniejących trudnościach związanych z próbami rozwiązania obydwu problemów, traktowanych wówczas jako swoiste tabu. T. Dąbek-Wirgowa miała jednak świadomość niejednoznaczności tożsamości poety, w związku z czym namawiała mnie do zbadania materiałów związanych z Macedońskim Kołem Literackim w Sofii i udziałem w nim autora Моторни песни.

${ }^{20}$ I. Dorovský, Balkan a Mediterán, Literárně historické a teoretické studie, Brno 1997.

${ }^{21}$ М. Ѓурчинов, Проблемот на билитерарноста и интерлитерарноста кај македонските писатели во ХІХ и во ХХ век, [w:] Компаративни студии, red. Б. Ристовски, Скопје 1998, s. $57-67$.

${ }^{22}$ Całkiem odmienny punkt widzenia reprezentuje część krytyki z Republiki Macedonii, która hołduje przekonaniu, że Vapcarov, podobnie jak dziewiętnastowieczni inni poeci i pisarze, np. Grigor Prličev, pisali w obcych językach z konieczności, natomiast ich tożsamość należy interpretować jednoznacznie, jako czysto macedońską; Г. Сталев, Историја на македонската књижевност, t. 1-2, Скопје 2001. Podobnie uważa Blaže Ristovski, którego zdaniem Vapcarov posługiwał się językiem bułgarskim z konieczności, choć jego twórczość odegrała rolę w rozwoju zarówno macedońskiej, jak i bułgarskiej literatury (idem, Беседа за делото на Вапиаров..., s. 21). Z kolei w 2008 roku — jako projekt finansowany przez Ministerstwo Kultury Republiki Macedonii - opublikowano antologię pt. Македонски дводомни писатели, w której znalazły się utwory nie tylko Vapcarova, lecz także wielu innych poetów (jak Christo Smirnenski) czy pisarzy (jak Anǵelko Kristić), należących do innych kanonów narodowych. 
naturalnej paraleli konwergencji językowej ${ }^{23}$. Stosowany przez I. Dorovskiego i M. Ǵurčinova termin ,poeta/pisarz posiadający podwójny/potrójny dom” nie oddaje istoty zjawiska, przeciwnie — z góry niejako zakłada pełną równorzędność każdego z członów takiego wyobrażonego domu, gdy tymczasem sytuacja jest bardziej złożona. W odniesieniu do Vapcarova mamy z jednej strony Bułgarię, ojczyznę szkoły i języka, w którym powstaje cała twórczość autora Прощално, z drugiej zaś - ojczyznę lokalną, Macedonię Piryńską, która dopiero pod wpływem działalności Macedońskiego Koła Literackiego zaczyna rozrastać się dla niego w nową ojczyznę - nową Macedonię, przy czym jedna nie niweluje drugiej. W terminie ,dvodomnost/trodomnost” kryje się zaś pułapka związana z tezą, przyjętą niejako z góry i zakładającą, że obydwa człony funkcjonują na tym samym poziomie znaczeniowym — w przypadku Vapcarova tak nie jest.

$\mathrm{Na}$ koniec spróbuję powrócić do pytania postawionego w tytule artykułu: dlaczego literatura macedońska nie chce być literaturą mniejszą? W czasach, które starałam się przypomnieć, projekt literatury macedońskiej rozwijany przez członków Koła bardzo dobrze mieścił się w typologii Deleuze'a i Guattari'ego. Propozycja zgłoszona przez francuskich badaczy w drugiej połowie XX wieku bardzo często jest odnoszona przez samych autorów do kontekstów z pierwszej połowy wieku XX, ponieważ budowali swoją koncepcję w istocie w oparciu o pisarzy z tego okresu. Co zatem stoi na przeszkodzie umieszczenia literatury macedońskiej w szerokim kontekście literatur mniejszych?

Odpowiedź tkwi, jak sądzę, w obrazie dwu kluczowych dyskursów literackich i historycznych, których kształt skorygowano po II wojnie światowej — mam tu na myśli bułgarską i macedońską oficjalną narracjęe24. Bułgarska traktowała (i to się nie zmieniło) Vapcarova i Macedońskie Koło Literackie jako integralną część tradycji własnej. U podstaw takiego rozumowania tkwi interpretacja pojęcia Macedonii jako Bułgarii, o czym pisała między innymi Teresa Dąbek-Wirgowa ${ }^{25}$. Również macedońska oficjalna narracja, ukształtowana po II wojnie światowej, traktuje poezję Vapcarova i Macedońskie Koło Literackie w Sofii jako część własnej tradycji.

Są to dwie dość poważne przeszkody utrudniające wprowadzenie literatury macedońskiej w kontekst literatur mniejszych, choć to właśnie ten kontekst wyjaśniałby bolesną dla wielu badaczy (nie tylko z Macedonii) kwestię zakorzenienia

${ }^{23}$ I. Sawicka, J. Sujecka, Wprowadzenie do bałkanologii. Etnosy - Języki - Areaty - Konceptualizacje, Warszawa 2015.

${ }^{24}$ Macedoński kanon narodowy powstaje wraz ze standaryzacją języka po II wojnie światowej, podczas gdy analizowany przeze mnie okres stanowi jeden z kontekstów dla jego późniejszego kształtu.

${ }^{25}$ T. Dąbek-Wirgowa, Kresy butgarsko-macedońskie, [w:] Kresy - pojęcie i rzeczywistość, red. i przedmowa K. Handke, Warszawa 1997, s. 239-252; Й. Суецка, Балкански места на паметта..., s. 138-154. 
w bułgarskiej tradycji literackiej i językowej nie tylko przedstawicieli Macedońskiego Koła Literackiego.

Wydaje się jednak, że istnieje jeszcze jedna, nie mniej poważna, przeszkoda asymilacji terminu ,literatury mniejsze" 26 do obydwu narodowych dyskursów w odniesieniu do przywołanego okresu. Vapcarov w obydwu narodowych kontekstach wychodzi poza kanon, zwłaszcza gdy czytamy jego utwory w oryginale — jest poetą mówiącym o uniwersalnym poniżeniu i uniwersalnej nostalgii za miejscem bliskim, utraconym, niemożliwym do osiągnięcia, i tym samym wychodzi zarówno poza partykularne ścieżki wytyczone dla literatur narodowych ${ }^{27}$, jak i dla literatur mniejszych.

\section{Bibliografia}

Dąbek-Wirgowa T., Historia literatury bułgarskiej, Zakład Narodowy im. Ossolińskich, Wrocław 1980.

Dąbek-Wirgowa T., Kresy butgarsko-macedońskie, [w:] Kresy - pojęcie i rzeczywistość, red. i przedmowa K. Handke, Instytut Slawistyki Polskiej Akademii Nauk, Warszawa 1997.

Deleuze G., Guattari F., Kafka: Toward a Minor Literature, przeł. D. Polan, „Theory and History of Literature" 30, University of Minnesota Press, Minneapolis-London 1986.

Dorovský I., Balkan a Mediterán, Literárně historické a teoretické studie, Masarykova univerzita, Brno 1997.

Literatury mniejsze Europy romańskiej, red. M. Loba, B. Łuczak, A. Gregori, Wydawnictwo Naukowe Uniwersytetu Adama Mickiewicza, Poznań 2012.

Macedonia: Land, Region, Borderland, conception and academic editing J. Sujecka, Wydawnictwo DiG, Warszawa 2013.

Sawicka I., Sujecka J., Wprowadzenie do bałkanologii. Etnosy - Języki - Areały - Konceptualizacje, Instytut Slawistyki Polskiej Akademii Nauk, Warszawa 2015.

Stownik języka polskiego, red. M. Szymczak, t. 1-3, PWN, Warszawa 1978-1981.

Stawowy-Kawka I., Historia Macedonii, Zakład Narodowy im. Ossolińskich, Wrocław 2000.

Sujecka J., Pojęcie Macedonii w wybranych dokumentach, publicystyce i tekstach folkloru z pierwszej połowy XX wieku. Od idei stowiańskiej jedności do federacji bałkańskiej, [w:] Między kultura ,niska”" a „,wysoka”": zjawiska językowe, literackie, kulturowe. Pamięci prof. dr hab.

2616 maja 2000 roku w Stołecznej Bibliotece Miejskiej w Sofii odbyło się cykliczne seminarium „akademickie lektury” (академични четеня), poświęcone 90. rocznicy urodzin Iwana Bogdanowa, zatytułowane „Малките литератури, смалените литератури. Poeta minore”. Zorganizowane przez pracowników kierunku nowa bułgarystyka z Nowego Bułgarskiego Uniwersytetu seminarium było bodaj pierwszą w Bułgarii otwartą dyskusją na poziomie akademickim nad pojęciem tzw. literatur mniejszych. W trakcie dyskusji próbowano odnieść termin „literatura mniejsza” do bułgarskiego kontekstu i postaci uczonego - prof. Ivana Bogdanova. Aleksandyr Kiosew, bułgarski badacz literatury i krytyk, przypomniał publikację Deleuze'a i Guattari'ego i wyjaśnił, jak francuscy badacze rozumieją ten termin. Literaturę bułgarską jako literaturę mniejszą usytuowano w kontekście literatury francuskiej i szerzej — wielkich literatur światowych.

${ }^{27}$ Uniwersalne cechy poezji Vapcarova analizuje bułgarski badacz — Radoswet Kołarow w swoim artykule: Разговорност и риторика в поезијата на Вапцаров, „Литературна мисъл” 8 , 1979, s. 60-82. 
Teresy Dąbek-Wirgowej, red. M. Korytkowska, Z. Darasz, G. Minczew, Wydawnictwo Uniwersytetu Łódzkiego, Łódź 2001.

Sujecka J., Bałkańskie miejsca pamięci. Pojęcie Macedonii w butgarskiej i macedońskiej czasoprzestrzeni kulturowej XX w., „Borussia” 2006, nr 37.

Wapcarow N., Pieśni wybrane, wybrał i opracował z oryginału bułgarskiego J. Lau, Wydawnictwo Książka i Wiedza, Warszawa 1954.

Гуурчинов М., Проблемот на билитерарноста и интерлитерарноста кај македонските писатели во ХІХ и во ХХ век, [w:] Компаративни студии, red. Б. Ристовски, МАНУ, Скопје 1998.

Коларов Р., Разговорност и риторика в поезијата на Вапизаров, „Литературна мисъл” 8, 1979. „Кормило” 1, 17 czerwca 1936, nr 37.

Ристовски Б., Беседа за делото на Вапиаров, [w:] Свечен собир по повод 80-годишнината од раѓането на Никола Вапиаров (17.X.1989), red. К. Томовски, Македонска академија на науките и уметностите, Скопје 1990.

Ристовски Б., Националната свест во литературно-културната дејност на Македонскиот литературен кружок во Софија, „Прилози. Одделение за лингвистика и литературна наука” 22, 1997, nr 1-2.

Сталев Г., Историја на македонската књижевност, t. 1-2, Institut za makedonska literatura, Скопје 2001.

Суецка Й., Балкански места на паметта. Терминът Македония и образът наНикола Вапцаров в блгарския и македонския времепространствен континуум, „Литературна мисъл” 2005, nr 2.

Тодоровски Т., Македонски дводомни писатели, НИД „Микена”, Битола 2008.

Тоциновски В. (избор, превод, редакција и белешки), Македонскиот Литературен Кружок, Софија, 1938-41, Документи, Архив на Македонија. Матица македонска, Скопје 1995.

Фонд Арсени Јовков 1882-1924, Архив на МАНУ.

Фонд Сматракалев М., кутија 10, Архив на Република Македонија.

\section{Why does Macedonian literature not want to be a minor literature?}

Summary

The author takes a look at a very interesting (and still under-investigated) project for creating a Macedonian literature that emerged among the members of what was known as the Macedonian Literary Circle in Sofia (1938-1941), in the context of the concept of "minor literatures" proposed after World War II, in 1975, by Gilles Deleuze and Félix Guattari. The French researchers' idea appears as a proposal that could build good solutions for the question of the Macedonian Literary Circle's project being rooted in the Bulgarian linguistic and cultural context, a question that is avoided by both Macedonian and Bulgarian discourse.

Keywords: Vapcarov, Smatrakalev, Macedonian Literary Circle in Sofia, Macedonian identity, minor literature 


\section{Зошто македонската книжевност не сака да биде споредна литература?}

\section{Резиме}

Во мојата статија анализирам многу интересен проект на македонската литература што го формулираат членовите на Македонскиот литературен кружок во Софија (1938-1941) во контекст на концептот за споредни книжевности предлаган од француските истражувачи Жил Делез и Феликс Гуатари (Gilles Deleuze, Félixa Guattari) во 1975 година. Идејата на француските истражувачи може да биде добро решение на одлаганото (од македонскиот и од бугарскиот дискурс) прашање за бугарските корени на предлаганиот проект од членовите на Македонскиот литературен кружок.

Клјучни зборови: Вапцаров, Сматракалев, Македонски литературен креужок во Софија, македонски идентитет, споредни книжевности 